\title{
Writing Anxiety, Self-efficacy, Effort, and Their Roles in Writing Achievement
}

\author{
Nawal Khelalfa \\ University of L'arbi Ben M'hidi, Oum El Bouaghi, Algeria, Nawalkhelalfa@Gmail.com
}

\begin{abstract}
Recurring observation has revealed language learners' successful completion of writing tasks at an acceptable and sometimes even impressive level only to complete the same tasks afterwards on evaluated assignments in a manner which sometimes fails to meet minimum standards. This leads to the assumption that such learners may be influenced by an extraneous factor functioning as an impediment in applying, upon evaluation, already-learned and mastered skills and knowledge. This factor is believed to come in one or more of the forms of Foreign Language Anxiety (FLA), which may influence and be influenced by other factors. The current study examined the association between some of these factors among Algerian EFL learners $(\mathrm{N}=148)$. Writing anxiety was measured using the Second Language Writing Anxiety Inventory (SLWAI; Cheng 2004). Two other factors, efficacy and effort, were measured using questions retrieved from the Academic Writing Motivation Questionnaire (AWMQ; Payne 2012). To test for an association between the variables, Spearman's correlation coefficient was used. Results from the analysis have revealed that a significant positive correlation exists between writing self-efficacy and effort put forth in writing, and between writing self-efficacy and writing achievement. A significant negative association was found between self-efficacy and anxiety. However, a non-significant negative association exists between anxiety and effort and between anxiety and writing achievement. These findings suggest that self-efficacy may mediate or may be mediated by writing anxiety and effort put forth into the writing task, which in turn may impact the overall achievement in writing courses. Implications for further research are discussed.
\end{abstract}

KEYWORDS: effort, Foreign Language Anxiety (FLA), writing anxiety, self-efficacy, writing achievement

\section{Introduction}

With growing emphasis on inter-individual differences of learners; researchers and educators are increasingly seeking to examine how various learner characteristics influence the language learning process. A range of factors are believed to shape outcomes in language learning; among these are cognitive, metacognitive, social, and affective factors (Olivares-Cuhat 2010). For instance, researchers have thus far established associations between success in language learning and various personality traits like introversion, extraversion, and willingness to communicate and language attainment (Dörney 2005). Hindrances to the language learning process have also been widely examined; for instance, anxiety, an affective factor, has been established as one of the major deterrents of language attainment (Bell \& McCallum 2012).

\section{Background}

Anxiety is believed to hinder language learning because language classrooms are believed to be "inherently face threatening environments" in which demands are placed on the learner to learn and implement "severely restricted language code" (Dörnyei 2001, 91). Hence, anxiety experienced uniquely in the context of language learning is believed to be a situation-specific type of anxiety referred to as Foreign Language Anxiety (FLA). FLA can be defined as the 'self perception, beliefs, feelings and behavior related to classroom language learning arising from the uniqueness of the language learning process' (Horwitz, Horwitz, \& Cope 1986, 128).

The role of anxiety in language learning has been examined since the 1970's in association with the various language skills: reading (Elkhafaifi 2005), listening (Brantmeier 2005), speaking (Hewitt \& Stephenson 2011) as well as vocabulary (Chen 2015) and grammar (Van Patten \& Glass 1999) and has been found to be a major source of inhibition. Furthermore, the field of EFL teaching and learning has recently shown growing interest in the role of anxiety in EFL writing (Cheng 2004; Hassan 2001).

Hassan (2001) describes writing anxiety as "a general avoidance of writing and of situations perceived by the individuals to potentially require some amount of writing accompanied by the 
potential for evaluation of that writing" (p.4). Writing anxiety has been found to correlate negatively with writing performance (Al Asmari 2013; Rezaei, Jafari, \& Younas 2014).

Other researchers, however, believe that anxiety itself is not the cause of performance; rather, it functions as a mediator to other mechanisms such as self-efficacy (SE) and confidence of learners possessed during such tasks. Hence, such mechanisms as the latter two are believed to be responsible for such effects on learning outcomes (Pajares \& Johnson 1994) in that the level of such mechanisms influences the level of anxiety experienced by a learner, which in turn influences performance.

This assertion is supported by Bandura, the pioneer of SE. He defined SE as one's sense of capabilities to carry out certain tasks or skills (Bandura 1977). Bandura (1988) asserted that individuals who "believe they can exercise control over potential threats do not engage in apprehensive thinking and are not perturbed by them. But those who believe they cannot manage threatening events that might occur experience high levels of anxiety arousal" (p.77). Hence, those with higher levels of SE are more able to block negative thoughts, are more self-assured (Bandura 1986) and are less threatened by challenging situations or assignments (Bandura 1995). In contrast, it is believed that those with low SE avoid seeking opportunities to improve or practice their skills since they believe themselves to be incompetent and maybe even unable to improve (Linnenbrink \& Pintrich 2003).

Within the field of EFL writing, SE is believed to play a major role (Hetthong \&Teo 2013). More specifically, Bottomley, Henk and Melnick (1997) and Lavelle (2006) believed that selfefficacy influences the amount of effort put forth in writing by language learners. Furthermore, Kirmızı and Kirmızı (2015) examined the association between writing SE and writing anxiety in the Turkish context and found negative and significant correlations between all subcomponents of selfefficacy and anxiety.

Majidifar and Oroji (2015) examined the relationship between Iranian EFL learners' writing SE, their test anxiety levels, and their writing performance and found a strong positive correlation between $\mathrm{SE}$ and performance. The researchers also found a negative moderate correlation between anxiety and performance. Finally, the learners with the highest levels of SE and lowest levels of anxiety outperformed the rest, and those with the lowest SE and highest anxiety levels performed the worst. Furthermore, Tola and Sree (2016) also found a significant positive correlation between writing selfefficacy and performance and a negative association between anxiety and writing.

The aforementioned literature has provided relatively consistent findings in representing the association between SE and anxiety, between writing SE and writing performance, and between SE and effort. However, the role of anxiety in language skills, such as writing, remains somewhat blurry since some researchers (Pajares \& Johnson 1994) believe anxiety to be only a mediator, aroused by a low level of SE, leading anxiety to be an apparent cause of performance.

The current study, therefore, aims to shed some light on the discrepancy, by re-examining the role of such variables as writing anxiety, writing SE, and effort in the writing achievement of EFL learners.

The researcher, therefore, conducted the current study with the following research questions in mind:

1. Is there any association between EFL learners' SE and writing performance?

2. Is there any association between EFL learners' SE and writing anxiety?

3. Is there any association between EFL learner' SE and effort put forth into writing?

4. Is there any association between EFL learners' writing anxiety and writing performance?

5. Is there any association between EFL learners' writing anxiety and effort put forth into writing?

\section{Method}

\subsection{Participants}

A convenience sampling method was used to investigate Algerian university students of EFL. A total of 148 students were selected from L'arbi Ben M'hidi University in Oum El Bouaghi, Algeria. Of the total sample, $38(25.7 \%)$ were male, 106 (71.6\%) were female, and $4(2.7 \%)$ did not report their gender. First 
year students covered $51.4 \%$ of the sample $(\mathrm{N}=76)$; second year students covered $13.5 \%$ of the sample $(\mathrm{N}=20)$, and third year students covered $33.1 \%(\mathrm{~N}=49)$. Three $(2.0 \%)$ students did not report their level.

\subsection{Measurement Tools}

The researcher used self-report measures to collect data on all of the variables. To measure writing anxiety, the researcher adapted the Second Language Writing Anxiety Inventory (SLWAI) developed by Chang (2004) as a tool for measuring writing-specific FLA. The questionnaire contains 22 items based on a 5-point Likert scale. Cheng (2004) reported strong internal consistency with a Cronbach alpha of .91. In the current study, Cronbach's alpha yielded a coefficient of .85; hence, the questionnaire holds strong internal consistency.

To measure writing self-efficacy and effort put forth into writing, the researcher adapted questions from the Academic Writing Motivation Questionnaire (AWMQ), devised by Payne (2012). The questionnaire originally contained 37 items measuring a range of factors, from extrinsic and intrinsic motivation to effort and self-efficacy. In the current study, the researcher used only the items which represented the two factors of self-efficacy and effort. Eight items were used to measure selfefficacy, and eight were used to measure effort. The items for both factors are based on a 5-point Likert scale. The AWMQ was originally reported to have a Cronbach's alpha of .95 (Payne, 2012). In this study, however, the researcher attained a Cronbach's alpha of .60 and .63 for self-efficacy and effort items, respectively.

Writing achievement was measured using an average of three scores attained by the participants on writing tests. The researcher asked the participants to state the highest score they have received on a writing test, the lowest score received, and another score. The researcher then calculated the average of the three scores and used it as an operationalization of writing achievement.

\subsection{Data Analysis}

In order to answer the aforementioned research questions, the researcher used the Statistical Package for the Social Sciences (SPSS) 25. First, the distribution of data was analyzed to test for the assumptions of Pearson's correlation coefficient. After the assumption of normality was violated, the researcher proceeded by running Spearman's correlation analysis for research questions 1-5.

\section{Results and Discussion}

The first research question sought to discover the association (if any) between EFL learners' writing SE and writing achievement. A Spearman's correlation was run to determine the relationship between 131 students' SE scores and writing achievement. Results have revealed (Table 1) that a significant (but weak) positive correlation exists between $\mathrm{SE}$ and achievement $\left(\mathrm{r}_{\mathrm{s}}(131)=.256, \mathrm{p}<.01\right)$ at the .01 level.

For the second question, which sought to examine the association between SE and writing anxiety, Spearman's correlation was also run. Results from the analysis (Table 1) have revealed a weak, yet significant, negative correlation between the two variables $\left(r_{\mathrm{s}}(146)=-.274, \mathrm{p}<.01\right)$ at the .01 level.

Again, a Spearman's correlation analysis was run for the third questions. In examining the relationship between SE and effort put forth into writing, results (Table 1) have revealed that a significant positive correlation exists between SE and effort $\left(\mathrm{r}_{\mathrm{s}}(146)=.398, \mathrm{p}<.01\right)$ at the .01 level.

The fourth question sought to examine whether an association exists between anxiety and writing achievement. Results have revealed that a negative but insignificant correlation exists between anxiety and achievement in writing $\left(\mathrm{r}_{\mathrm{s}}(146)=-.124, \mathrm{p}>.05\right)$.

To answer the fifth question, which sought to examine whether an association exists between anxiety and effort, a Spearman's correlation was used. Results have again revealed a negative but insignificant correlation between anxiety levels and effort put forth $\left(\mathrm{r}_{\mathrm{s}}(146)=-.063, \mathrm{p}>.05\right)$. 
Table 1. Spearman's correlation coefficients

\begin{tabular}{|c|c|c|c|c|c|c|}
\hline & & & SE & ANXIETY & EFFORT & $\begin{array}{c}\text { ACHIEVEMEN } \\
\mathrm{T} \\
\end{array}$ \\
\hline \multirow{12}{*}{$\begin{array}{l}\text { Spearman's } \\
\text { rho }\end{array}$} & & Correlation Coefficient & 1.000 & $-.274^{\star *}$ & $.398^{\star *}$ & $.256^{*}$ \\
\hline & SE & Sig. (2-tailed) & . & .001 & .000 & .003 \\
\hline & & $\mathrm{N}$ & 148 & 148 & 148 & 131 \\
\hline & & Correlation Coefficient & $-.274^{* *}$ & 1.000 & -.063 & -.124 \\
\hline & ANXIETY & Sig. (2-tailed) & .001 & . & .449 & .158 \\
\hline & & $\mathrm{N}$ & 148 & 148 & 148 & 131 \\
\hline & & Correlation Coefficient & $.398^{* *}$ & -.063 & 1.000 & $.173^{*}$ \\
\hline & EFFORT & Sig. (2-tailed) & .000 & .449 & . & .048 \\
\hline & & $\mathrm{N}$ & 148 & 148 & 148 & 131 \\
\hline & & Correlation Coefficient & $.256^{* *}$ & -.124 & $.173^{*}$ & 1.000 \\
\hline & ACHIEVEMEN & Sig. (2-tailed) & .003 & .158 & .048 & \\
\hline & $\mathrm{T}$ & $\mathrm{N}$ & 131 & 131 & 131 & 131 \\
\hline
\end{tabular}

Findings from this study are relatively in line with those of previous researchers. For example, the current study parallels the findings of Bottomley, Henk and Melnick (1997) and Lavelle (2006) since the results have revealed that SE influences the amount of effort put forth by the language learner. Findings from the current study also support those of Kirmizi and Kirmiz1 (2015) since a significant association between SE and anxiety was found. Furthermore, this study supports previous research which has claimed that writing SE is associated with writing performance (Majidifar \& Oroji 2015). The current study, however, does not support the findings that anxiety significantly influences writing performance (Majidifar \& Oroji 2015; Tola \& Sree 2016).

Since results from the current study have revealed no significant association between the two variables or between anxiety and effort put forth into the writing task, one may be able to refer back to Bandura (1986, 1988) and Pajares and Johnson (1994). Bandura (1986, 1988) believed that SE prevents individuals from becoming apprehensive, even in the face of challenging tasks. Additionally, Pajares and Johnson (1994) believed that anxiety is simply a mediator of factors such as SE and confidence, and that anxiety is not a direct independent variable in language learning. This study seems to support Bandura's $(1986,1988)$ and Pajares and Johnson's (1994) view, since anxiety does not seem to be a major determinant of writing achievement in itself. Rather, the major determinant of performance in this case is SE, and the major determinant of anxiety is also SE. The current findings, therefore, lead the researcher to assume that anxiety may simply function as a mediator of SE and not a single independent variable to writing achievement.

\section{Conclusion}

The current findings seem to support the assertion that $\mathrm{SE}$ is a major factor in language learning and, more specifically, in writing. Also, from the current study, one may support the assertion that SE is a factor in the level of anxiety experienced and in the effort put forth by the learners. The discrepancy which still remains, however, lies in the claimed association between anxiety and writing performance. Although much support lies in the claim that the association is significant, the current study claims otherwise; rather, it supports the claim that anxiety is determined by SE, which is a major determinant of effort and achievement.

Although some research has been conducted on the interplay of SE, anxiety, and achievement, to the researcher's knowledge, Dörnyei (2010) explained that individual differences (such as SE and 
anxiety levels, among others) are rarely examined in interaction with each other. This study serves as an illustration of the need for more research on such interaction. Specifically, more research should be conducted on the interaction between such variables as SE, anxiety, effort, and achievement.

\section{References}

Al Asmari, A. 2013. "Investigation of writing strategies, writing apprehension, and writing achievement among Saudi EFLmajor students." International Education Studies 6(11): 130.

Bandura, A. 1986. Social foundations of thought and action: A social cognitive view. Eaglewood Cliffs: Prentice Hall.

Bandura, A. 1988. Self-efficacy conception of anxiety. Anxiety research, 1(2): 77-98.

Bandura, A. 1995. Self-efficacy in changing societies. New York, NY: Cambridge University Press. http://dx.doi.org/10.1017/CBO9780511527692.

Bandura, A. 1997. Self-efficacy: The exercise of control. New York: Freeman.

Bell, S. M., \& McCallum, R. S. 2012. "Do foreign language learning, cognitive, and affective variables differ as a function of exceptionality status and gender?" International Education 42(1): 85.

Bottomley, D., Henk, W., \& Melnick, S. 1997. "Assessing children's views about themselves as writers using the Writer SelfPerception Scale.” The Reading Teacher 51(4): 286-291.

Brantmeier, C. 2005. "Anxiety about L2 learning or L2 reading tasks? A study with advanced language learners." The Reading Matrix 5(2): 67-85.

Chen, X. 2015. "A tentative study of vocabulary learning anxiety in college English learning in China." International Journal of English Linguistics 5(1): 104.

Cheng, Y. 2004. "A measure of second language writing anxiety: Scale development and preliminary validation." Journal of Second Language Writing 13(4): 313-335. http://dx.doi.org/10.1016/j.jslw.2004.07.001.

Dörnyei, Z. 2001. Motivational strategies in the language classroom. Cambridge: Cambridge University Press.

Dörnyei, Z. 2005. The psychology of the language learner: Individual differences in second language acquisition. Mahwah, NJ: Lawrence Erlbaum.

Dörnyei, Z. 2010. "The relationship between language aptitude and language learning motivation: Individual differences from a dynamic systems perspective." In E. Macaro (Ed.), Continuum companion to second language acquisition (pp. 247-267). London: Continuum.

Elkhafaifi, H. 2005. "Listening comprehension and anxiety in the Arabic language classroom." The Modern Language Journal 89(2): 206-220. Retrieved from http://onlinelibrary.wiley.com.eres.library.manoa.hawaii.edu/doi/10.1111/j.15404781.2005.00275.x/abstract.

Hassan, B. 2001. "The relationship of writing apprehension and self-esteem to the writing quality and quantity of EFL university students." Mansoura Faculty of Education Journal 39: 1-36.

Hetthong,, R. \& Teo, A. 2013. "Does writing self-efficacy correlate with and predict writing performance?" International Journal of Applied Linguistics \& English Literature 2(1): 157-167.

Hewitt, E., \& Stephenson, J. 2011. "Foreign language anxiety and oral exam performance: A replication of Phillips's $M L J$ study.” The Modern Language Journal 96: 170-189. doi:10.1111/j.1540-4781.2011.01174.

Horwitz, E. K., Horwitz, M. B., \& Cope, J. 1986. "Foreign language classroom anxiety.” The Modern Language Journal 70(2): $125-132$.

Kırmız1, Ö., \& Kırmızı, G. D. 2015. “An investigation of L2 learners' writing self-efficacy, writing anxiety and its causes at higher education in Turkey." International Journal of Higher Education 4(2): 57.

Lavelle, E. 2006. “Teachers' self-efficacy for writing." Electronic Journal of Research in Educational Psychology 8(4-1): 73-84.

Linnenbrink, E. A., \& Pintrich, P. R. 2003. "The role of self-efficacy beliefs in student engagement and learning in the classroom." Reading and Writing Quarterly 19:119-137.

Majidifar, S., \& Oroji, M. 2015. "The relationship among test anxiety, self-efficacy, and writing performance among Iranian intermediate EFL learners." International Journal of Language and Linguistics 3 (6): 323-327.mhn

Olivares-Cuhat, G. 2010. "Relative importance of learning variables on L2 performance." Linguistik Online 43: 99-116.

Pajares, F., \& Johnson, M. J. 1994. "Confidence and competence in writing: The role of writing self-efficacy, outcome expectancy and apprehension.” Research in the Teaching English 28: 313-331.

Payne, A. R. 2012. Development of the academic writing motivation questionnaire (Doctoral dissertation, University of Georgia).

Rezaei, M. M., Jafari, S. M., \& Younas, M. 2014. "Iranian EFL students' writing anxiety: levels, causes and implications." English for Specific Purposes World 42(15): 1-10.

Tola, T. \& Sree, P. 2016. "Students' writing self-efficacy and writing apprehension relating to their writing performance: Reflection on Ethiopian first year university students." International Research Journal of Humanities, Language and Literature 3 (1): 22-36.

VanPatten, B., \& Glass, W. R. 1999. "Grammar learning as a source of language anxiety: A discussion." Affect in foreign language and second language learning. A practical guide to creating a low-anxiety classroom atmosphere, 89-105. Boston: McGraw-Hill. 